HUSTLER, K. \& HOWELLS, W. W. 1987. Breeding periodicity, productivity and conservation of the Martial Eagle. Ostrich 58:135-138.

HUSTLER, K. \& HOWELLS, W. W. 1988a. Breeding biology of the White-headed Vulture in Hwange National Park, Zimbabwe. Ostrich 59:21-24.

HUSTLER, K. \& HOWELLS, W. W. 1988b. The effect of primary production on breeding success and habitat selection in the African Hawk Eagle. Condor 90:583-587.

HUSTLER, K. \& HOWELLS, W. W. 1988c. Breeding biology of the Hooded and Lappet-faced Vultures in the Hwange National Park, Zimbabwe. Honeyguide 34:109-115.

HUSTLER, K. \& HOWELLS, W. W. 1989. Habitat preference, breeding success and the effect of primary productivity on Tawny Eagles Aquila rapax in the tropics. Ibis 131:33-40.

IRWIN, M. P. S. 1981. The birds of Zimbabwe. Quest, Harare.

KEMP, A. C. \& CALBURN, S. 1987. The owls of southern Africa. Struik Winchester, Cape Town.

MUNDY, P. J. 1982. The comparative biology of southern African vultures. Vulture Study Group, Johannesburg.

NEWTON, I. 1979. Population ecology of raptors. T. \& A. D. Poyser, Berkhamsted.

NEWTON, I., MARQUISS, M., WEIR, D. M. \& MOSS, D. 1977. Spacing of Sparrowhawk nesting territories. Joumal of Animal Ecology 46:425-441.

PENNYCUICK, P. J. 1976. Breeding of the lappet-faced and white-headed vultures (Torgos tracheliotus Forster and Trigonoceps occipitalis Burchell) on the Serengeti Plains, Tanzania. East African Wildlife Journal 14:67-84.

RICKLEFS, R. E. 1979. Ecology. Nelson, Middlesex.

RUTHERFORD, M. C. 1978. Primary production ecology in southern Africa. Pp. 623-659 in Werger, M. (ed.). Biogeography and ecology of southern Africa. Vol. 1. W. Junk, The Hague.

SMTHERS, R. H. N. 1983. The Mammals of the southern African Subregion. University of Pretoria, Pretoria.

STEYN, P. 1982. The birds of prey of southern Africa. David Philip, Cape Town.

TARBOTON, W. R. 1980. Avian biomass in some Transvaal woodlands. Proceedings 4th Pan-African Omithological Congress; 113-143.

TARBOTON, W. R. \& ALLAN, D. G. 1984. The status and conservation of the birds of prey of the Transvaal. Transvaal Museum Monograph 3:1-115.

VERNON, C. J. 1979. Prey remains from seven Tawny Eagle nests. Honeyguide 100:22-24.

Accepted 26 September 1989

\title{
ANNOUNCEMENT
}

\section{The Paul Richards Centre, Korup National Park, Cameroun}

The family and friends of Professor Paul Richards plan to celebrate his recent 80th birthday by raising funds to build and equip the Paul Richards Centre at Korup National Park near Mundemba, Cameroun. Many tropical ecologists agree that Paul Richards' book The tropical rain forest published in 1952 initiated the modern era of tropical rain forest research. It is therefore most apt that his influence should be be commemorated by a Centre in what is regarded as the most species-rich rain forest in Africa.

Donations are invited to the 'Paul Richards Korup Fund', c/o 57 Selwyn Road, Cambridge CB3 9EA, England - UK. 